\title{
Studies on the sphaerocerid flies of synanthropy and hygienic importance in Japan (Diptera)
}

\section{Records of the forty species}

\author{
Toshihiko HaYashi \\ Department of Medical Zoology, Faculty of Medicine, Tokyo Medical and Dental University, \\ Yushima, Bunkyo-ku, Tokyo 113, Japan
}

(Received: September 25, 1985)

Key words: Sphaeroceridae, Diptera, synanthropy, new records, Japan.

\begin{abstract}
Forty species of synanthropic and hygienically important sphaerocerid flies are recorded from Japan. Of these, 6 genera and 22 species are newly recorded from Japan. Sphaerocera pseudomonilis Nishijima and Yamazaki is briefly redescribed.
\end{abstract}

\section{INTRODUCTION}

In the family Sphaeroceridae, many species inhabit in Japan, but few species are recorded up to the present (Richards, 1963, 1964; Mihara et al., 1983; Nishijima and Yamazaki, 1984).

In my previous paper (Hayashi, 1986), I gave a key to the synanthropic and hygienically important species from Japan. This paper deals with records of the 40 species previously keyed, 6 genera and 22 species of which are newly recorded here from Japan.

\section{Sphaerocera curvipes}

Latreille, 1804

(Japanese name: Ashibuto Hayatobibae)

Sphaerocera curvipes Latreille, 1804, Hist. Nat. Crust. Insect, 14: 394.

This species is commonly found on dung of various domestic animals, manure heaps and human feces.
Distribution: Japan, Europe, Afghanistan, Tibet, Mongolia, North America, South America, Australia, New Zealand and Africa.

Specimens examined: 1, Akkeshi, Kushiro, Hokkaido, 31. VII. 1980, T. Hayashi; 5ㅎㅇ, 3요, Tokachishimizu, Tokachi, Hok-

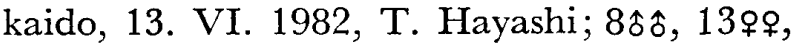
Kamishihoro, Tokachi, Hokkaido, 14. VI. 1982, T. Hayashi; 9송, 12오으, Hidaka, Hidaka, Hokkaido, 10. VI. 1982, T. Hayashi; 12소, 6오, Noboribetsu, Iburi, Hokkaido, 16.

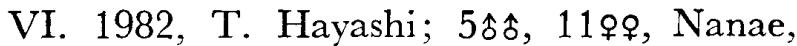
Oshima, Hokkaido, 21. VI. 1982, T. Hayashi; 19, Setagaya, Tokyo, 7. V. 1982,

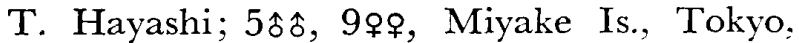
9. VII. 1982, T. Hayashi; 4令占, 1오, Aso, Kumamoto, 10. VIII. 1979, M. Iwasa.

\section{Sphaerocera pseudomonilis Nishijima and Yamazaki, 1984 (Japanese name: Himeashibuto Hayatobibae)}

(Figs. 1 and 2)

Sphaerocera pseudomonilis Nishijima and 
Yamazaki, 1984, Mem. Papers Dr. H. Kôno Twentieth Anniv.: 82.

This is a little known species, so I briefly redescribe below.

Almost black species. Body length about 2.1-3.0 mm.

Head entirely dusted, 1 vi strong, 3-4 small peristomal bristles; eye diameter about the same length as genal width; antenna brownish; arista long, about $0.8-0.9 \mathrm{~mm}$.

Thorax entirely dusted; mesonotum with 4 rows of minute spines; sternopleura with a ventral bristle; all coxae yellowish, fore femur and tibia black, fore tarsus and mid and hind legs dark brown; dorsal part of fore femur shining on basal $1 / 2$; wing hyaline with brown veins; halter yellowish brown.

Abdomen with black tergites and brownish membraneous part; male genitalia as in Figs. 1 and 2; surstylus short and rounded, with many short spines interiorly.

This species is found on horse dung, manure heaps and decayed vegetable matter. It has been known only from Japan (Hokkaido and Honshu).

Distribution: Japan.

Specimens examined: 4占占, 5우, Kamikawa, Kamikawa, Hokkaido, 15. VIII. 1982,

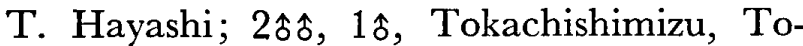
kachi, Hokkaido, 13. VI. 1982, T. Hayashi; 1f, 2요, Obihiro, Tokachi, Hokkaido, 11. VI. 1982, T. Hayashi; 1ㅎ, Chitose, Ishikari, Hokkaido, 16. VI. 1982, T. Hayashi; 1ㅅ, Noboribetsu, Iburi, Hokkaido, 16. VI. 1982, T. Hayashi; 1ㅅ, 1ㅇ, Mori, Oshima, Hokkaido, 18. VI. 1982, T. Hayashi; 3와, Kiyosato, Nagano, 29. VI. 1984; T. Hayashi; 1ㅅ, Mt. Myoko, Niigata, 1. VII. 1984, T. Hayashi; 19, Asagiri Plateau, Yamanashi, 27. VIII. 1983, T. Hayashi.

\section{Lotobia pallidiventris (Meigen, 1830) \\ (Japanese name: Niseibohada Hayatobibae)}

Borborus pallidiventris Meigen, 1830, Syst. Beschr. europ. zweift. Insekt., 6: 204.

This species was captured on horse dung, but rarely on cattle dung and manure heaps only in Hokkaido.
Distribution: Japan, Europe, Afghanistan, Nepal, Mongolia, Tunisia and Africa. According to Papp (1978), this seems to be a Palaearctic species, and the records from Ethiopian Region need revision.

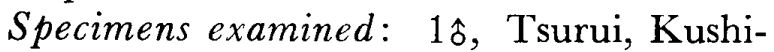
ro, Hokkaido, 12. VIII. 1982, T. Hayashi;

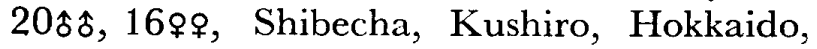

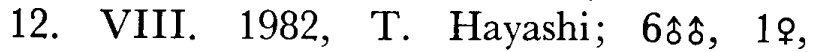
Kamishihoro, Tokachi, Hokkaido, 14. VI.

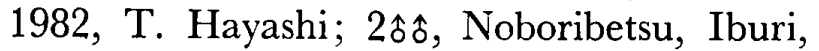

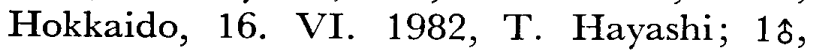
Kuromatsunai, Shiribeshi, Hokkaido, 19. VII. 1982, T. Hayashi.

\section{Ischiolepta scabricula (Haliday, 1836) \\ (Japanese name: Chibiibohada Hayatobibae)}

Sphaerocera scabricula Haliday, 1836, Entomol. Mag., 3: 320.

This species is very rare. Nishijima and Yamazaki (1984) recorded 3 individuals from Hokkaido, and I captured only 1 individual on cattle dung.

Distribution: Japan, Europe, Afghanistan and Africa.

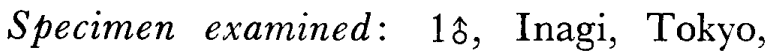
19. V. 1982, T. Hayashi.

\section{Ischiolepta pusilla (Fallén, 1820)}

\section{(Japanese name: Ibohada Hayatobibae)}

Copromyza pusilla Fallén, 1820, Dipt. Sueciae Heteromyzides, 5: 8.

Nishijima and Yamazaki (1984) recorded this species based on the character of male fore and hind femora not being thick from Japan. According to Roháček and Papp (1984), the male of Ischiolepta pusilla (Fallén, 1820) has often swollen femora and the present species can be distinguished from Ischiolepta vaporariorum (Haliday, 1836) only by the genital structures. I. pusilla recorded by Nishijima and Yamazaki (1984) is most probably the present species.

I captured this species on sheep and cattle manure heaps.

Distribution: Japan, Europe, Canary Is., Afghanistan, North and South America, New 
Zealand, Tunisia and Africa.

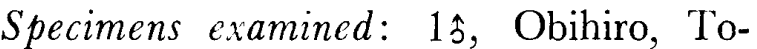
kachi, Hokkaido, 11. VI. 1982, T. Hayashi; 1§, 1, Kamikawa, Kamikawa, Hokkaido, 14. VIII. 1982, T. Hayashi.

\section{Ischiolepta oedopoda Papp, 1972 \\ (Japanese name: Fusageibohada Hayatobibae)}

Ischiolepta oedopoda Papp, 1972, Fol. entomol. hung., 25: 469.

This species seems to be rare. All materials examined were captured on cattle dung in pasture. Some individuals were teneral, so cattle dung seems to be one of breeding media of larvae of this species. It is recorded here from Japan for the first time.

Distribution: Japan, Hungary, Caucasus, Mongolia and North Korea.

Specimens examined: 3소, 9오, Nanae, Oshima, Hokkaido, 19. VI. 1982, T. Hayashi; 11송, 17오, same locality, 21. VI. 1982,

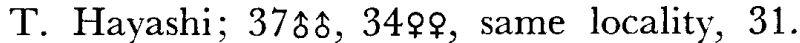
VII. 1982, T. Hayashi; 21ㅎํ, 24오, same locality, 24. VIII. 1982, T. Hayashi.

\section{Lotophila atra (Meigen, 1830) (Japanese name: Togenashi Hayatobibae)}

Borborus ater Meigen, 1830, Syst. Beschr. europ. zweifl. Insekt., 6: 203.

This species is commonly found on cattle dung in pasture in Hokkaido, and a few individuals were captured on manure heaps and deer dung.

Distribution: Japan, Europe, Soviet Union, Afghanistan, Mongolia, China, North America and Mexico.

Specimens examined: 1ㅅ, Akkeshi, Kushiro, Hokkaido, 31. VII. 1980, T. Hayashi;

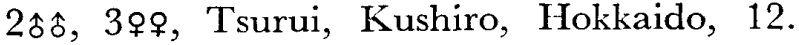
VIII. 1982, T. Hayashi; 1q, Obihiro, Tokachi, Hokkaido, 6. IX. 1981, T. Hayashi; 1ई, Chitose, Ishikari, Hokkaido, 16. VI.

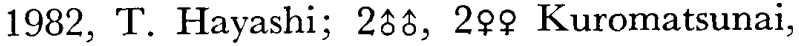
Shiribeshi, Hokkaido, 19. VII. 1982, T. Hayashi; 1ㅅ, 6웅 Nanae, Oshima, Hokkaido, 21. VI. 1982, T. Hayashi.

\section{Copromyza equina Fallén, 1820} (Japanese name: Sesuji Ohhayatobibae)

Copromyza equina Fallén, 1820, Dipt. Succiae Heteromyzides, 2: 6.

This species is abundantly found on dung of various domestic animals, manure heaps and human feces in Hokkaido, but is not so abundant in Honshu.

Distribution: Japan, Europe, North America and Zaire.

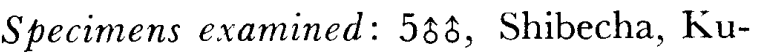
shiro, Hokkaido, 12. VIII. 1982, T. Hayashi; 10ㅎㅅ, 6요, Obihiro, Tokachi, Hokkaido, 11.

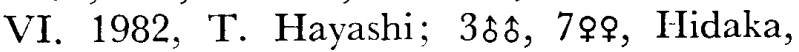
Hidaka, Hokkaido, 10. VI. 1982, T. Hayashi; 5소, 4요, Noboribetsu, Iburi, Hokkaido, 16. VI. 1982, T. Hayashi; 3소, 6우, Nanae, Oshima, Hokkaido, 21. VI. 1982, T. Hayashi, 26łô, 26qọ, Hakodate, Oshima, Hokkaido, 9. VI. 1982, T. Hayashi; 2와, Kuriyagawa, Iwate, 16. V. 1974, S. Shinonaga; 19, Fujisawa, Kanagawa, 13. IV. 1983, T. Hayashi.

\section{Crumomyia nipponica (Richards, 1968) \\ (Japanese name: Madara Ohhayatobibae)}

Copromyza (Crumomyia) nipponica Richards, 1968, Ann. Mag. Nat. Hist., 13: 617.

This species is not so abundant. I captured it on cattle and horse manure heaps and decayed vegetable matter. It has been recorded only from Japan.

Distribution: Japan.

Specimens examined: 3 와, Obihiro, Tokachi, Hokkaido, 14. VI. 1982, T. Hayashi;

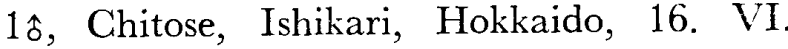
1982, T. Hayashi; 1ㅅ, 4요, Mori, Oshima, Hokkaido, 18. VI. 1982, T. Hayashi; 1의, Yaen Pass, Tokyo, 3. V. 1970, R. Kano; 1영 Setagaya, Tokyo, 14. IV. 1982, T. Hayashi; 4ㅊㅀ, 4우, Hachioji, Tokyo, 7. IV. 1983, T. Hayashi. 


\section{Borborillus sordida} (Zetterstedt, 1847)

\section{(Japanese name: Makiba Hayatobibae)}

Copromyza sordida Zetterstedt, 1847, Dipt. Scand., 6: 2484.

This species is abundant in Hokkaido in summer. I captured it on manure heaps and horse, cattle and sheep dung.

Distribution: Japan, Europe, Asia, North America and Africa.

Specimens examined: 1ㅅ, Nemuro, Nemuro, Hokkaido, 31. VII. 1980, T. Hayashi;

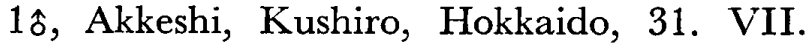
1980, T. Hayashi; 8ㅎํ, 8요, Shibecha, Kushiro, Hokkaido, 12. VIII. 1982, T. Hayashi; 4소, 3오, Kamishihoro, Tokachi, Hokkaido,

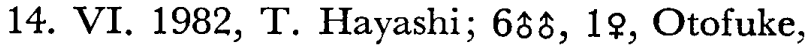
Tokachi, Hokkaido, 11. VIII. 1982, T. Hayashi; 6소, 6우, Obihiro, Tokachi, Hokkaido, 11. VI. 1982, T. Hayashi; 3ㅎ̂ㅅ, 1우, Kamikawa, Kamikawa, Hokkaido, 15. VIII. 1982, T. Hayashi; 2\%o, Hakodate, Oshima, Hokkaido, 9. VI. 1982, T. Hayashi.

\section{Borborillus marginatis (Adams, 1905) (Japanese name: Minamimakiba Hayatobibae)}

Borborus marginatis Adams, 1905, Kansas Univ. Sci. Bull., 3: 198.

This species is widespread in the Old World tropics and Australian Region, and in Japan it is found only in southern part. It is recorded here from Japan for the first time.

Distribution: Japan, Southeast Asia, Australia and Africa.

Specimens examined: 1ㅅ, Kuneinaka, Tsushima Is., Nagasaki, 15. X. 1979, M. Iwasa; 1ㅅ, Ada, Kunigami, Okinawa Is., Okinawa, 13. VII. 1974, S. Shinonaga; 10今소, 10와, Miyako Is., Okinawa, 2. VII. 1977, M. Iwasa.

\section{Borborillus vitripennis (Meigen, 1830)$$
\text { (Japanese name: }
$$ Higebutomakiba Hayatobibae)}

Borborus vitripennis Meigen, 1830, Syst. Beschr. europ. zweifl. Insekt., 6: 206.

This species is rarely captured on horse dung and manure heaps.

Distribution: Japan, Europe and Siberia.

Specimens examined: 1ㅇ, Kotoni, Ishikari, Hokkaido, 25. VI. 1951, I. Hattori; 19, Shichinohe, Aomori, 26. VIII. 1980, M. Iwasa; 1ㅇ, Nasu, Tochigi, 17. VIII. 1980, M. Iwasa.

\section{Borborillus somogyii (Papp, 1973)} (Japanese name: Ajiamakiba Hayatobibae)

(Figs. 3 and 4)

Copromyza (Borborillus) somogyii Papp, 1973, Acta zool. Acad. Sci. Hung., 19: 378.

This species belongs to Borborillus costalis complex. According to Papp (1973), this species complex includes 4 species and each species can be distinguished by the differences of male genitalia. I recognized some species of this complex from Japan, but I could not identify them by means of Papp's descriptions and illustrations except Borborillus somogyii (Papp). This species is identified by the shape of male genitalia and bifurcate posterior part of 5 th sternite (Figs. 3 and 4). It is recorded here from Japan for the first time.

Distribution: Japan, Hungary and Mongolia.

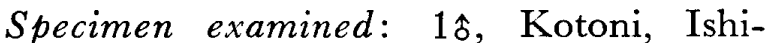
kari, Hokkaido, 25. VI. 1951, I. Hattori.

\section{Loptocera (Leptocera) nigra Olivier, 1813 (Japanese name: Magarimyaku Hayatobibae)}

Leptocera nigra Olivier, 1813, Mem. Soc. Agr. Dept. Seine-et-Oise., 16: 489.

This species is closely related to Leptocera (Leptocera) salatigae (de Meijere) and can be distinguished only by the postabdominal structures.

Richards (1963, 1964) recorded Leptocera curvinervis Stenhammer (synonym of this species) from Chichijima of Ogasawara Is. and Kobe of Honshu, but the materials I 
examined from Ogasawara Is. were all $L$. (L.) salatigae.

According to Roháček (1982a), this species seems to be one of the commonest sphaerocerid fly recorded from temperate areas of the Palaearctic Region, but it is not so common in Japan. A few individuals were captured on cattle manure heaps, decayed vegetable matter and muddy field.

Distribution: Japan, Europe, Soviet Union and North Korea.

Specimens examined: 1ㅇ, Tama, Tokyo, 15. IV. 1984, S. Shinonaga; $1 \hat{\delta}$, same locali-

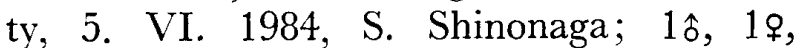
Enzan, Yamanashi, 9. VIII. 1983, T.

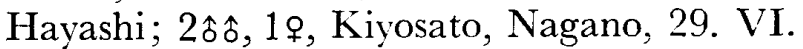
1984, T. Hayashi.

\section{Leptocera (Leptocera) salatigae (de Meijere, 1914) \\ (Japanese name: Nisemagarimyaku Hayatobibae)}

Limosina salatigae de Meijere, 1914, Tijdschr. Entomol., 57: 269.

This species is widespread in the Oriental and Australian Regions. The record from Fujisawa of Kanagawa prefecture is new to the Palaearctic Japan. I captured it on decayed vegetable matter. It is recorded here from Japan for the first time.

Distribution: Japan, throughout the Oriental Region, Papua New Guinea and Australia.

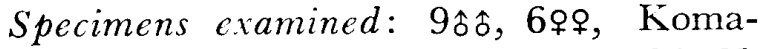
gari, Chichijima, Ogasawara, Tokyo, 25. V. 1973, S. Shinonaga; 1ㅅ, Fujisawa, Kanagawa, 24. IV. 1984, T. Hayashi.

\section{Leptocera (Leptocera) caenosa (Rondani, 1880)}

\section{(Japanese name: Fusahige Hayatobibae)}

Limosina caenosa Rondani, 1880, Bull. Soc. entomol. ital., 12: 36.

This species is often found in houses, and sometimes occurs in a large number. I captured it on decayed vegetable matter and in houses and woods. It is recorded here from Japan for the first time.

Distribution: Cosmopolitan.

Specimens examined: 2ईई, 2오, Sapporo,
Ishikari, Hokkaido, 18. IV. 1984, K. Hattori, 7소옹 5우, Nanae, Oshima, Hokkaido, 22. VIII. 1982, T. Hayashi; 2소, 3우, Hakodate, Oshima, Hokkaido, 3. VIII. 1982, T. Hayashi; 5소, 4우, Yushima, Bunkyo, Tokyo,

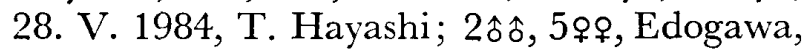

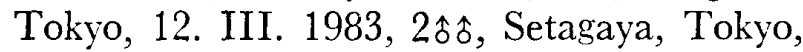
21. IV. 1982, T. Hayashi; 1\%, Meguro, Tokyo, 3. V. 1982, H. Kurahashi; 3今ోf, 1의, Hachioji, Tokyo, 10. VI. 1983, T. Hayashi.

\section{Leptocera (Rachispoda) fuscipennis (Haliday, 1833) \\ (Japanese name: Hamabe Hayatobibae)}

Borborus fuscipennis Haliday, 1833, Entomol. Mag., 1: 178.

This species is mainly littoral species. Mihara et al. (1983) reported a housefrequenting case of this species in Tokyo.

Distriution: Japan, Europe, Mongolia, New Zealand and Africa.

Specimens examined: 4令, Tokyo, 21. VII. 1984, T. Hayashi.

\section{Leptocera (Rachispoda) subtinctipennis (Brunetti, 1913) (Japanese name: Hamadara Hayatobibae)}

Limosina subtinctipennis Brunetti, 1913, Rec. Indian Mus., 8: 174.

This species is widespread in the Oriental Region and Oceania. It resembles to Leptocera (Rachispoda) boninensis Richards, but can be distinguished from it by having maculated legs. I captured a few individuals on cattle dung. It is recorded here from Japan for the first time.

Distribution: Japan, Canary Is., South East Asia, Solomon Is. and Africa.

Specimens examined: $1 \hat{\delta} \hat{\delta}, 2$ 우요, Inagi, Tokyo, 19. V. 1982, T. Hayashi; 2§ઈ, Tama, Tokyo, 13. V. 1984, S. Shinonaga; 1ㅅ, Miyake Is., Tokyo, 8. VII. 1982, T. Hayashi; 3q9, Tsukui, Kanagawa, 3. V. 1984, T. Hayashi. 
19 Leptocera (Rachispoda) lutosa

(Stenhammar, 1854)

(Japanese name: Futoge Hayatobibae)

(Fig. 5)

Limosina lutosa Stenhammar, 1854, K. svenska vet. Akad. Handl., 74: 380.

There are some species of the subgenus Rachispoda captured on cattle dung and manure heaps in Japan. This subgenus is very complicated and I could identify only Leptocera (Rachispoda) lutosa (Stenhammar). This species is distinguished from the other members of the subgenus Rachispoda by having $4 s c$, a patch of short black spines on hind trochanter ventrally (Fig. 5) and no distinct $a c$ bristles.

This species is not abundant. I captured it on the lakeside. It is recorded here from Japan for the first time.

Distribution: Japan, Europe, Soviet Union, Afghanistan and North America.

Specimen examined: 1ㅇ, Nanae, Oshima, Hokkaido, 21. VII. 1982, T. Hayashi.

\section{Thoracochaeta brachystoma (Stenhammar, 1854)}

(Japanese name: Susubane Hayatobibae)

Limosina brachystoma Stenhammar, 1854,

K. svenska vet. Acad. Handl., 3: 401.

The members of the genus Thoracochaeta are all associated to decayed organic matter on seashore. This species is abundantly found on the seashore.

Distribution: Cosmopolitan.

Specimens examined: 7송, 5우, Kamiiso, Oshima, Hokkaido, 20. VI. 1982, T. Haya-

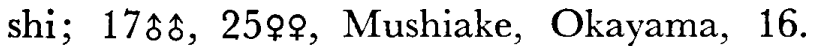
II. 1984, H. Kurahashi.

\section{Thoracochaeta zosterae (Haliday, 1833) \\ (Japanese name: \\ Kitasusubane Hayatobibae)}

Borborus zosterae Haliday, 1833, Entomol. Mag., 1: 177.

This species is found on the seashore. It is recorded here from Japan for the first time.

Distribution: Japan, Europe and North
America.

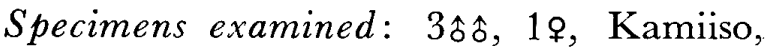
Oshima, Hokkaido, 20. VI. 1982, T. Hayashi.

22 Thoracochaeta johnsoni (Spuler, 1925)

\section{(Japanese name: Setouchi Hayatobibae)}

Leptocera johnsoni Spuler, 1925, Can. Entomol., 57: 120.

Kurahashi et al. (1984) reported mass occurrence of this species in Okayama prefecture in the 36th annual meeting of the Japan Society of Sanitary Zoology. The details will be reported by them.

This species is abundantly found on the seashore, but some individuals from Hokkaido were captured on cattle manure and horse dung.

Distribution: Japan and North America.

Specimens examined: 3 \%ㅇ, Toyoura, Iburi, Hokkaido, 10. VI. 1982, T. Hayashi;

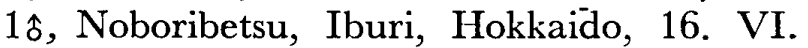

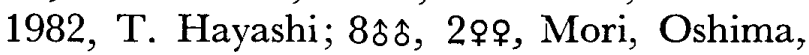

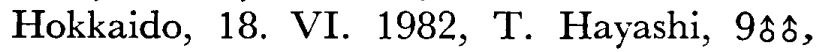
6오, Kamiiso, Oshima, Hokkaido, 20. VI.

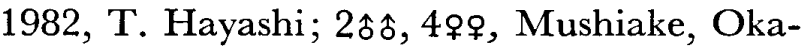
yama, 16. II. 1984, H. Kurahashi.

\section{Poecilosomella punctipennis (Wiedemann, 1824)}

(Japanese name: Madara Hayatobibae)

Copromyza punctipennis Wiedemann, 1824, Anal. Entomol.: 59.

This species is widespread in the Old World tropics, The Australian Region and the Oceania. In Japan it is found in the southern part. It is found abundantly on dung of various kinds of domestic animals and manure heaps. This genus and species are recorded here from Japan for the first time.

Distribution: Japan, Southeast Asia, New Guinea, New Caledonia, Fiji, Mariana Is., Garolin Is., Samoa and Africa.

Specimens examined: $1 \hat{\delta}, 1$ if, Miedake, Kagoshima, 9. VIII. 1979, M. Iwasa; 19, Yona, Okinawa Is., Okinawa, 19. X. 1973, R. Kano; 1ㅅ, Sonai, Iriomote Is., Okinawa, 6. I. 1953, T. Shiraki; 1ㅎ, 1오, Nakara, Iriomote Is., Okinawa, 4. I. 1953, T. Shiraki. 


\section{Poecilosomella aciculata Deeming, 1969 \\ (Japanese name: Asijiromadara Hayatobibae)}

Poecilosomella aciculata Deeming, 1969, Bull. Br. Mus. Nat. Hist., 23: 60.

Up to the present, this species has been recorded only from Nepal. In Japan, it is found in the southern part. It is recorded here from Japan for the first time.

Distribution: Nepal and Japan.

Specimens examined: 2कo, Mt. Ariake, Tsushima Is., Nagasaki, 26. VI. 1969, S.

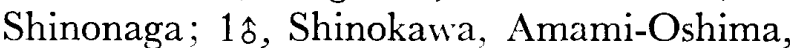
Kagoshima, 15. V. 1953, T. Shiraki.

\section{Coproica ferruginata (Stenhammar, 1854) (Japanese name: Sabiirokebuka Hayatobibae)}

Limosina ferruginata Stenhammar, 1854, $K$. svenska vet. Akad. Handl., 3: 397.

This species is much abundantly found on cattle manure heaps and horse dung, and also on dried cattle dung and muddy field. It is recorded here from Japan for the first time.

Distribution: Cosmopolitan.

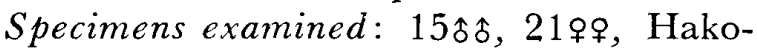
date, Oshima, Hokkaido, 9. VI. 1982, T. Hayashi; 12ईई, 12요, Setagaya, Tokyo, 21. IV. 1982, T. Hayashi; 9ł̊s, 17워, Inagi, To-

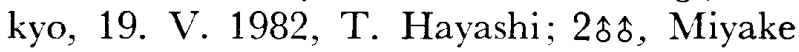
Is., Tokyo, 9. VII. 1982, T. Hayashi; 7占昘, 7우, Sasuna, Tsushima Is., Nagasaki, 3. V. 1982, M. Takeda.

26 Coproica vagans (Haliday, 1833) (Japanese name: Kebuka Hayatobibae)

Borborus vagans Haliday, 1833, Entomol. Mag., 1: 178.

This species is abundantly found on cattle dung, manure heaps and muddy field. It is recorded here from Japan for the first time.

Distribution: Cosmopolitan.

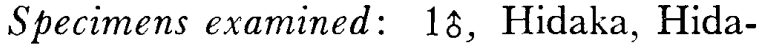
ka, Hokkaido, 10. VI. 1982, T. Hayashi; 9소, 6와, Nitona, Chiba, 5. VII. 1982, A.

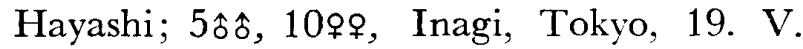
1982, T. Hayashi.
27 Coproica acutangula

(Zetterstedt, 1847)

(Japanese name:

Kehanekebuka Hayatobibae)

Limosina acutangula Zetterstedt, 1947, Dipt. Scand., 6: 2499.

This species is abundantly found on horse dung and manure heaps.

Distribution: Japan, Europe, Soviet Union, Afghanistan, Mongolia, North America, Hawaii and Africa.

Specimens examined: $3 \hat{\jmath} \hat{\delta}$, Obihiro, Tokachi, Hokkaido, 10. IX. 1981, T. Hayashi; 1ิे, Kuromatsunai, Shiribeshi, Hokkaido, 19. VII. 1982, T. Hayashi; 26ㅎ̂, 30요, Setagaya, Tokyo, 21. IV. 1982, T. Hayashi.

\section{Coproica coreana Papp, 1979 (Japanese name: Chosenkebuka Hayatobibae)}

Coproica coreana Papp, 1979, Opusc. Zool. Budapest, 16: 98.

This species is abundantly found on dung and manure heaps of various domestic animals. It is recorded here from Japan for the first time.

Distribution: Japan and North Korea.

Specimens examined: 11ㅎㅅ, 12우, Obihiro, Tokachi, Hokkaido, 11. VI. 1982, T. Hayashi; 5ㅎํ, 3우, Rubeshibe, Abashiri,

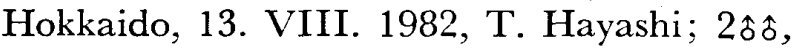
2우, Nanae, Oshima, Hokkaido, 21. VI. 1982, T. Hayashi; 3소, 1, Setagaya, Tokyo, 7. V. 1982, T. Hayashi; 2ર̂̊̂, Sasuna, Tsushima Is., Nagasaki, 3. V. 1982, M. Takeda.

\section{Coproica hirtula (Rondani, 1880) (Japanese name: Chibikebuka Hayatobibae)}

Limosina hirtula Rondani, 1880, Bull. Soc. entomol. ital., 12: 38.

This species is abundantly found in the same environments as the preceding species.

Distribution: Cosmopolitan.

Specimens examined: $56 \hat{\jmath} \hat{\jmath}, 15$ 우, Kamikawa, Kamikawa, Hokkaido, 15. VIII. 1982,

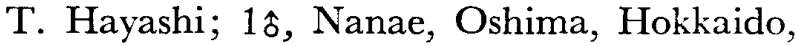
21. VI. 1982, T. Hayashi; 4소, 1ㅇ, Urayasu, Chiba, 5. VI. 1985, T. Hayashi; 2화, 5우, Setagaya, Tokyo, 7. V. 1982, T. Hayashi. 
30 Coproica hirticula Collin, 1956 (Japanese name: Nisechibikebuka Hayatobibae)

Coproica hirticula Collin, 1956, J. Soc. Br. Entomol., 5: 178.

This species is rare. I captured it on cattle manure heaps and hen dung in spring. It is recorded here from Japan for the first time.

Distribution: Japan, Europe and Australia.

Specimens examined: 1ㅅ, Setagaya, To-

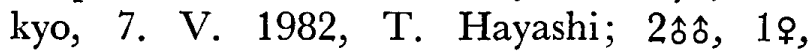
Fujisawa, Kanagawa, 13. IV. 1983, T. Hayashi.

\section{Coproica lugubris (Haliday, 1836) (Japanese name: Sujigurokebuka Hayatobibae)}

Limosina lugubris Haliday, 1836, Entomol. Mag., 3: 332.

This species is found on cattle dung in pastures. It is recorded here from Japan for the first time.

Distribution: Japan, Europe, Tunisia, Afghanistan and North Korea.

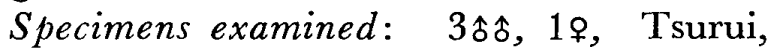
Kushiro, Hokkaido, 12. VIII. 1982, T. Hayashi; 10소, 6오오, Kamikawa, Hokkaido, 15. VIII. 1982, T. Hayashi; 9ㅎㅅ, 8오, Nanae, Oshima, Hokkaido, 24. VIII. 1982, T. Hayashi; 29ㅎㅅ, 7ㅇ, Inagi, Tokyo, 19. V. 1982, T. Hayashi; 7소, 6ㅇํ, Miyake Is., Tokyo, 9. VII. 1982, T. Hayashi.

32 Coproica pusio (Zetterstedt, 1847) (Japanese name:

\section{Himesujigurokebuka Hayatobibae)}

Limosina pusio Zetterstedt, 1847, Dipt. Scand., 6: 2496.

This species can be captured in the same environments as the preceding species. It is recorded here from Japan for the first time.

Distribution: Japan, Europe, Afghanistan and Mongolia.

Specimens examined: $3 \hat{\text { ôf}}$, 2우우, Teshikaga, Kushiro, Hokkaido, 12. VIII. 1982, T. Hayashi; 6ํํㅇ, 5오, Obihiro, Tokachi,
Hokkaido, 11. VIII. 1982, T. Hayashi; 2^^ر, 3ㅇ, Kamikawa, Kamikawa, Hokkaido, 15. VIII. 1982, T. Hayashi.

\section{Chaetopodella scutellaris (Haliday, 1836) \\ (Japanese name: Birodochibi Hayatobibae)}

Limosina scutellaris Haliday, 1836, Entomol. Mag., 3: 329.

All individuals examined were captured on cattle dung in pastures. This genus and species are recorded here from Japan for the first time.

Distribution: Japan, Europe, Afghanistan and Africa.

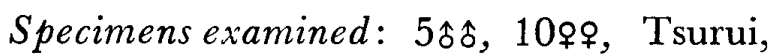
Kushiro, Hokkaido, 12. VIII. 1982, T. Hayashi; 4ㅊํ, 2우, Teshikaga, Kushiro,

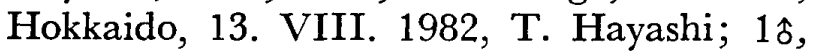
Asahikawa, Kamikawa, Hokkaido, 17. VIII. 1982, T. Hayashi; 1ㅅ, 1ㅇ, Kuromatsunai, Shiribeshi, Hokkaido, 19. VII. 1982, T. Hayashi; 7소, 11워, Nanae, Oshima, Hokkaido, 19. VI. 1982, T. Hayashi; $1 \hat{\delta}$, Asagiri Plateau, Yamanashi, 27. VIII. 1983, T. Hayashi.

\section{Telomerina flavipes (Meigen, 1830) (Japanese name: Umazura Hayatobibae)}

Borborus flavipes Meigen, 1830, Syst. Beschr. europ. zweifl. Insekt., 6: 208.

This species is found on dung and manure of various kinds of domestic animals and decayed vegetable matter. I have reared this species from hen dung. Some authors reported that it was often found in houses in Europe. This genus and species are recorded here from Japan for the first time.

Distribution: Japan, Europe, Tunisia, Soviet Union, Afghanistan, Mongolia, North America, Africa, Australia and New Zealand.

Specimens examined: 4占全, Obihiro, Tokachi, Hokkaido, 28. XI. 1980, T. Hayashi; 23송, 34우우, Chitose, Ishikari, Hokkaido, 16.

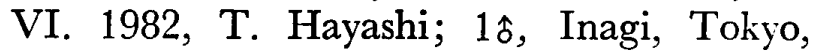
19. V. 1982, T. Hayashi; 4રิ่, Fujisawa, 
Kanagawa, 13. IV. 1983, T. Hayashi.

35 Telomerina levifrons

(Spuler, 1925)

(Japanese name:

Sujiguroumazura Hayatobibae)

Leptocera (Scotophilella) levifrons Spuler, 1925, J. N. Y. Entomol. Soc., 33: 77.

This species is found on manure of various kinds of domestic animals and decayed vegetable matter in spring. It is recorded here from Japan for the first time.

Distribution: Japan, Czechoslovakia and North America.

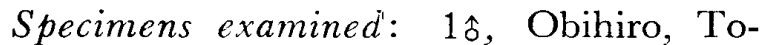
kachi, Hokkaido, 11. VI. 1982, T. Hayashi;

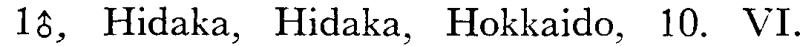
1982, T. Hayashi; 1ㅅ, Setagaya, Tokyo, 21. IV. 1982, T. Hayashi; 1ㅇ, Mt. Takao, Tokyo, 7. VI. 1984, T. Hayashi; 28소, 12와의, Fujisawa, Kanagawa, 13. IV. 1983, T. Hayashi; 4令, 14요, same locality, 24. IV. 1984, T. Hayashi.

\section{Opalimosina (Opalimosina) mirabilis (Collin, 1902) (Japanese name: Ohtogechibi Hayatobibae)}

Limosina mirabilis Collin, 1902, Entomol. mon. Mag., 13: 59.

This species is abundantly found on dung of various domestic animals, manure heaps, seaweed and decayed vegetable matter. It resembles Opalimosina (Opalimosina) calcarifera (Roháček, 1975), but in O. calcarifera, the spine on hind tibia is smaller. This genus and species are recorded here from Japan for the first time.

Distribution: Japan, Europe, Canary Is., Nepal, Mongolia, North America, Australia, New Zealand and Hawaii.

Specimens examined: 33송, 13오, Tokachishimizu, Tokachi, Hokkaido, 13. VI.

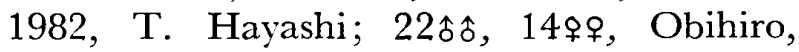
Tokachi, Hokkaido, 11. VI. 1982, T. Hayashi; 5ㅊํ, Chitose, Ishikari, Hokkaido,

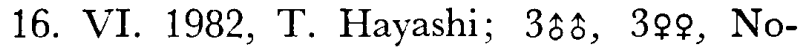
boribetsu, Iburi, Hokkaido, 16. VI. 1982, T. Hayashi; 6ई̊f, 7오, Nanae, Oshima, Hok-

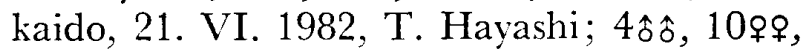

Hakodate, Oshima, Hokkaido, 9. VI. 1982, T. Hayashi; 2 ofo, Setagaya, Tokyo, 7. V.

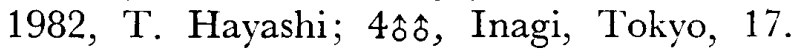

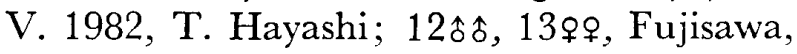

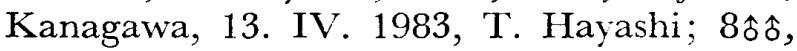
7qo, Mt. Myoko, Niigata, 1. VII. 1984, T. Hayashi.

37

\section{Spelobia (Bifronsina) bifrons (Stenhammar, 1854) (Japanese name: Kiharahime Hayatobibae)}

Limosina bifrons Stenhammar, 1854, $K$. svenska vet. Akad. Handl., 3: 401.

This species is commonly found on dung and manure heaps of various kinds of domestic animals, decayed vegetable matter and seaweed. This genus and species are recorded here from Japan for the first time.

Distribution: Japan, Europe, Canary Is., Soviet Union, Afghanistan, Africa, Samoa and Hawaii.

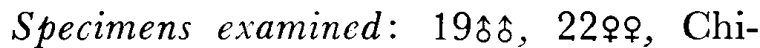
tose, Ishikari, Hokkaido, 16. VI. 1982, T.

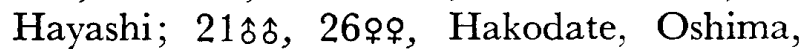
Hokkaido, 9. VI. 1982, T. Hayashi; 4占占, 8오, Inagi, Tokyo, 19. V. 1982, T. Hayashi; 4소, 12우, Fujisawa, Kanagawa, 13. IV. 1983, T. Hayashi; 8소, 10 오, Sasuna, Tsushima Is., Nagasaki, 3. V. 1982, M. Takeda.

\section{Spelobia (Spelobia) luteilabris (Rondani, 1880) \\ (Japanese name: Hime Hayatobibae)}

(Figs. 6 and 7)

Limosina luteilabris Rondani, 1880, Bull. Soc. entomol. ital., 12: 32.

This species can be distinguished from the other members of the subgenus Spelobia by the differences of male genitalia (Figs. 6 and 7 ).

It was captured on cattle manure heaps and decayed vegetable matter. In Europe, it is often found on house windows and in food processing buildings (Zuska and Lastovka, 1969; Roháček, 1983). It is recorded here from Japan for the first time.

Distribution: Japan, Europe and New Zealand.

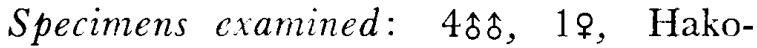


date, Oshima, Hokkaido, 9. VI. 1982, T.

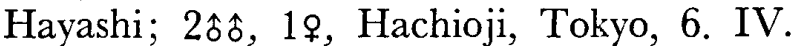
1983, T. Hayashi; 13소, 12웅, Fujisawa, Kanagawa, 13. IV. 1983, T. Hayashi.

\section{$39 \quad$ Pullimosina (Pullimosina) heteroneura (Haliday, 1836) (Japanese name: Kiashichibi Hayatobibae)}

Limosina heteroneura Haliday, 1836, Entomol. Mag., 3: 331.

This species was recorded as frequent in various buildings of the food industry in Europe (Roháček, 1983). It is rather rare in Japan and all individuals were captured on decayed vegetable matter. This genus and species are recorded here from Japan for their first time.

Distribution: Japan, Europe, Canary Is., Soviet Union, Afghanistan, Formosa, North America, Africa, Australia, New Zealand and Hawaii.

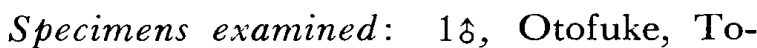
kachi, Hokkaido, 11. VIII. 1982, T. Hayashi; 1, Nanae, Ohima, Hokkaido, 22. VIII. 1982, Hayashi, 1t, 1\%, Urayasu, Chiba, 5. VI. 1985, T. Hayashi; 19, Hachioji, Tokyo, 7. IV. 1983, T. Hayashi; 1^, same locality, 18. V. 1984, T. Hayashi.

\section{Spinilimosina rufifrons (Duda, 1925) (Japanese name: Togehanechibi Hayatobibae)}

Leptocera (Scotophilella) brevicostata var. rufifrons Duda, 1925, Arch. Naturgesch., 90: 164.

Distribution: Japan, Formosa, India, New Guinea, Africa and Hawaii.

Specimens examined: 7송, 1우, Kitafukurozawa, Ogasawara Is., Tokyo, 19. V. 1973, S. Shinonaga.

\section{AGKNowledgements}

I express my sincere thanks to Mr. N. Fukuhara of National Institute of Agricultural Sciences and Dr. M. Iwasa of Obihiro University of Veterinary Medicine and Agriculture for their kindness in lending me specimens. My hearty thanks are also due to Dr. H. Kurahashi of National Institute of Health for his valuable suggestions and providing me with material, and Prof. R. Kano and Dr. S. Shinonaga of Tokyo Medical and Dental University for their kind advices and reading the manuscript.

\section{REFERENCES}

Hayashi, T. (1986): Studies on the sphaerocerid flies of synanthropy and hygienic importance in Japan (Diptera). I. The key to species of the flies. Jpn. J. Sanit. Zool., 37: 113-120.

Mihara, M., H. Kurahashi, S. Kondo and S. Kawahara (1983): A house-frequenting case of Leptocera fuscipennis (Haliday) (Diptera, Sphaeroceridae). I. Morphology and bionomics. Jpn. J. Sanit. Zool., 34: 7-12 (in Japanese). Mihara, M., H. Kurahashi, S. Kondo and S. Kawahara (1983): Ditto. II. Mass breeding and migration. Ibid., 34: 13-20 (in Japanese).

Nishijima, Y. and K. Yamazaki (1984): Studies on the sphaerocerid flies from Hokkaido, with descriptions of two new species (Diptera, Sphaeroceridae). In: Memorial Papers of Dr. Kôno, Twentieth Aniversary, Sapporo, pp. 7395.

Papp, L. (1973): Sphaeroceridae (Diptera) from Mongolia. Acta Zool. Acad. Sci. Hung., 19: $369-425$.

Papp, L. (1978): Sphaeroceridae (Diptera) in the collection of the Hungarian Natural History Museum. IV. Sphaerocerinae. Ibid., 24: 371395.

Richards, O. W. (1963): Sphaeroceridae (Borboridae). In: Insects of Micronesia, Diptera, vol. 14, pp. 109-134.

Richards, O. W. (1964): New species of Diptera Sphaeroceridae from the Pacific Region, with notes on some other species. Ann. Mag. Nat. Hist., 6: 609-619.

Roháček, J. (1982a): Revision of the subgenus Leptocera (s. str.) of Europe (Diptera, Sphaeroceridae). Entomol. Abh., 46: 1-44.

Roháček, J. (1982b): A monograph and reclassification of the previous genus Limosina Macquart (Diptera, Sphaeroceridae) of Europe. Beitr. Entomol., Berlin, 32: 195-282.

Roháček, J. (1983): Ditto, Part II. Ibid., 33: 3-195.

Roháček, J. and L. Papp (1984): Ischiolepta Lioy (Diptera, Sphaeroceridae): Two new species and taxonomical notes. Acta Zool. Hung., 30: 469-479.

Zuska, J. and P. Lastovka (1969): Species-composition of the dipterous fauna in various types of food-processing plants in Czechoslovakia. Acta Entomol. Bohemoslov., 66: 201-221. 


\section{摘 要}

人類親和性および衛生上重要な日本産 ハヤトビバエ科の研究

II . 日本産重要種 40 種類の記録

日本産ハヤトビバェ科の八工類中，人類親和性およ び衛生上重要と認められる40種類を報告した。 6 属 22 種類は日本新記録であった. また Sphaerocera pseudomonilis は日本から記載された種であるが，これま で特徴があまり知られていないので雄外部生殖器を図 示し，簡単に再記載した。

Figs. 1-2 Sphaerocera pseudomonilis.

1 , male genitalia in lateral view; 2 , ditto in caudal view.

Figs. 3-4 Borborillus somogyii.

3 , male genitalia in lateral view; 4 , male 5 th sternite.

Fig. 5 Leptocera (Rachispoda) lutosa, hind coxa in anterior view. Figs. 6-7 Spelobia (Spelobia) luteilabris.

6 , male 5 th sternite; 7 , male genitalia in lateral view.

Scales: Figs. $1-4,6-7 ; 0.1 \mathrm{~mm}$. Fig. $5 ; 0.2 \mathrm{~mm}$. 

